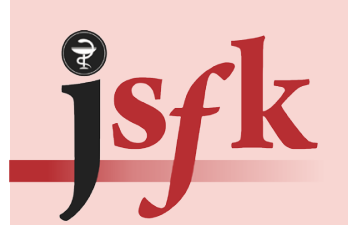

Jurnal Sains Farmasi \& Klinis (p- ISSN: 2407-7062 | e-ISSN: 2442-5435)

diterbitkan oleh Ikatan Apoteker Indonesia - Sumatera Barat homepage: http://jsfkonline.org

\title{
Evaluasi Penggunaan Obat Antidiabetik pada Pasien Diabetes Melitus Tipe-2 di Suatu Rumah Sakit Pemerintah Kota Padang - Sumatera Barat
}

\author{
(Antidiabetic Use Evaluation in Type-2 Diabetes Mellitus' Patients \\ on a Public Hospital at Padang City - West Sumatra)
}

\author{
Dedy Almasdy ${ }^{1}$, Dita Permata Sari ${ }^{1}$, Suharti ${ }^{1}$, Deswinar Darwin ${ }^{2}$, \& Nina Kurniasih ${ }^{3}$ \\ ${ }^{1}$ Fakultas Farmasi Universitas Andalas \\ ${ }^{2}$ RSUP Dr. M. Djamil Padang. \\ ${ }^{3}$ RSUD Dr. Rasyidin Padang
}

\begin{abstract}
Keywords: antidiabetic; drug use evaluation; hospital pharmacy.

ABSTRACT: The appropriateness of antidiabetic usege on a public hospital in Padang - West Sumatra has been studied. This study was a descriptive study with prospective data collection on type-2 diabetes mellitus patient's medical record. Evaluation of the appropriateness based on criteria established earlier, such as appropriate of indication, appropriate of patient, appropriate of medication, appropriate of regiment, and appropriate of drug administration. Evaluation also has been done to the drug interaction. The results showed that antidiabetic usage on that hospital ware 100\% appropriate in term of appropriate of indication, appropriate of medication, and appropriate of drug administration. While evaluation to appropriate of patient and appropriate of regiment were $95.59 \%$ and $40.82 \%$ respectively.

Kata kunci: antidiabetik; evaluasi penggunaan obat; farmasi rumah sakit.

ABSTRAK: Kajian terhadap ketepatan penggunaan antidiabetik pada suatu rumah sakit pemerintah di Padang, Sumatera Barat telah dilakukan. Penelitian ini berupa kajian deskriptif, menggunakan rekam medis sebagai sumber data. Ketepatan penggunaan obat didasarkan pada kriteria yang telah ditetapkan terlebih dahulu, meliputi beberapa indikator, yaitu; ketepatan indikasi, ketepatan penderita, ketepatan regimen dosis dan ketepatan rute pemberian. Kajian juga dilakukan terhadap potensi terjadinya interaski obat. Hasil penelitian menunjukkan bahwa penggunaan obat antidiabetik pada rumah sakit tersebut $100 \%$ tepat indikasi dan tepat rute pemberian. Sedangkan kajian terhadap ketepatan penderita dan regimen dosis masing-masingnya hanya sebesar $95.59 \%$ dan $40.82 \%$. Selain itu juga ditemukan potensi interaksi obat.
\end{abstract}

\section{PENDAHULUAN}

Diabetes Melitus (DM) adalah suatu penyakit atau gangguan metabolisme kronis dengan multi etiologi yang ditandai dengan tingginya kadar gula darah disertai dengan gangguan metabolisme karbohidrat, lipid dan protein serta menghasilkan komplikasi kronik seperti mikrovaskular, makrovaskular, dan gangguan neuropati sebagai akibat insufisiensi fungsi insulin [1].

Pada tahun 2000 diperkirakan prevalensi diabetes untuk semua kelompok usia adalah $2.8 \%$, angka ini diperkirakan akan meningkat hingga 4.4\% pada tahun 2030. Dengan kata lain, jumlah penderita diabetes diperkirakan akan meningkat dari 171 juta di tahun 2000 hingga 366 juta pada tahun 2030 [2]. Di Indonesia, prevalensi DM adalah sebesar $5.7 \%$, tetapi hanya $1.5 \%$ responden yang mengetahui dirinya menderita penyakit ini. Sedangkan berdasarkan jenis kelamin, DM lebih banyak dijumpai pada perempuan dibanding lakilaki [3].

Berdasarkan patologinya, DM dibedakan kepada emapat golongan, yaitu; DM tipe-1
*Corresponding Author: Sylvi Irawati (Pusat Informasi Obat dan Layanan

Kefarmasian (PIOLK) Universitas Surabaya)

email: dedyalmasdy@ffarmasi.unand.ac.id

\section{Article History:}

Received: 5 Sep 2015

Published: 1 Nov 2015
Accepted: 21 Sep 2015

Available online: 13 Jan 2016 
disebabkan oleh kerusakan sel $\beta$ pankreas, DM tipe-2 disebabkan oleh gangguan pada reseptor sel $\beta$ pankreas sehingga sel tidak mampu memproduksi insulin dalam jumlah dan kualitas mencukupi, DM tipe-3 disebabkan oleh intoleransi glukosa yang timbul selama masa kehamilan (diabetes gestasional), dan DM tipe lain disebabkan oleh berbagai faktor yang menyebabkan jumlah atau kualitas insulin tidak mencukupi. DM tipe lain ini antara lain disebabkan oleh defek genetik fungsi sel beta, defek genetik kerja insulin, penyakit eksokrin pankreas, endokrinopati, akibat kerja obat atau zat kimia, infeksi, imunologi dan sindroma genetik lain $[4,5,6]$.

Tujuan penatalaksaan pasien DM dalam jangka pendek adalah agar tercapainya target pengendalian glukosa darah pada kadar normal serta hilangnya gejala-gejala klinik yang menyertainya. Sedangkan pada jangka panjang adalah dapat mencegah atau mengurangi komplikasi [1,7]. Untuk mencapai tujuan ini, pada dasarnya ada dua pendekatan dalam penatalaksanaan DM, yaitu pendekatan tanpa obat (diet dan modifikasi gaya hidup) dan pendekatan dengan obat (farmakoterapi). Meskipun demikian kenyataannya pada penanganan penyakit DM seringkali tidak terkontrol sebagaimana mestinya [4].

Diabetes yang tidak terkontrol dengan baik dapat menimbulkan komplikasi. Pada tahap akut, komplikasi diabetes terjadi akibat gangguan metabolik seperti hipoglikemia atau hiperglikemia sedangkan pada tahap lanjut, gangguan ini terjadi akibat kerusakan mikrovaskular dan makrovaskular [5]. Komplikasi mikrovaskular berupa retinopati, neuropati dan nefropati sedangkan komplikasi makrovaskular berupa penyakit jantung koroner, strok dan penyakit vaskular periferal [7]. Sedangkan komplikasi DM di Indonesia menurut laporan umumnya berupa neuropati, penyakit jantung koroner, ulkus diabetikum, retinopati dan nefropati [8]. Salah satu factor yang sangat berperan dalam timbulnya komplikasi pada penyakit DM ini adalah penggunaan obat yang tidak tepat $[5,7,8]$.

Di Indonesia, berbagai penelitian telah dilakukan untuk menilai ketepatan penggunan obat pada pasien DM tipe-2 [9,10,11,12,13]. Akan tetapi sejauh ini belum ada laporan tentang penggunaan obat anti diabetes pada pada pasien DM tipe-2 di Kota Padang, Sumatera Barat. Karena itu penelitian ini bertujuan untuk mengetahui ketepatan penggunaan obat antidiabetik pada pada penderita DM tipe-2 pada suatu rumah sakit pemerintah di Kota Padang Sumatera Barat. Melalui penelitian ini diharapkan dapat menjadi masukan bagi berbagai pihak dalam meningkatkan pelayanan pada penderita DM, sehingga dapat meningkatkan pengendalian terhadap penyakit DM.

\section{METODE PENELITIAN}

Penelitian ini adalah penelitian deskriptif. Data dikumpulkan secara prospektif, pada bulan Mei Juli 2012 pada suatu rumah sakit pemerintah di Kota Padang Sumatera Barat. Kriteria inklusi pada penelitian ini adalah pasien DM tipe-2 rawat inap, dengan atau tanpa komplikasi, serta mendapatkan terapi obat antidiabetik.

Sumber data yang digunakan adalah catatan medis pasien, kemudian dianalisa secara kualitatif untuk melihat ketepatan penggunaan obat dengan menggunakan beberapa indikator, yaitu; tepat indikasi, tepat penderita, tepat obat, tepat regimen dosis dan tepat rute pemberian.

Ketepatan penggunaan obat ditetapkan berdasarkan kriteria yang telah ditetapkan terlebih dahulu. Kriteria ini dikembangkan berdasarkan Pedoman Diagnosa dan Terapi (PDT) SMF Penyakit Dalam di rumah sakit tersebut (khususnya untuk penanganan penyakit DM) dan 
literatur-literatur resmi lainnya yang terpercaya (Lampiran). Kriteria ini kemudian divalidasi melalui sebuah seminar ilmiah yang dihadiri oleh para akademisi dan praktisi.

\section{HASIL DAN DISKUSI}

Jumlah pasien DM tipe-2 yang medapatkan perawatan selama waktu penelitian adalah sebayak 59 orang, sedangkan yang memenuhi kriteria inklusi adalah sebanyak 40 orang. Gambaran umum pasien-pasien yang memenuhi kriteria inklusi tersebut sebagaimana pada Tabel 1

Mayoritas pasien adalah perempuan. Temuan ini mengkonfirmasi informasi dari literatur yang mengatakan bahwa wanita memiliki faktor resiko yang lebih besar terhadap DM daripada laki-laki, khususnya mereka yang memiliki riwayat diabetes gestasional atau riwayat melahirkan bayi dengan berat $4 \mathrm{~kg}$ atau lebih. Secara umum diketahui bahwa pasien dengan diabetes gestasional memiliki resiko untuk berkembang menjadi DM tipe-2. Selain itu, riwayat melahirkan bayi dengan berat badan melebihi $4 \mathrm{~kg}$ berisiko untuk menderita DM tipe-2 pada suatu saat kelak $[1,14]$.

Rata-rata usia pasien adalah 49,5 $\pm 18,7$ tahun, dengan rentang usia 27-72 tahun, sedangkan jumlah pasien terbanyak pada rentang umur 5059 tahun. Temuan ini sesuai dengan literatur yang menyatakan bahwa penyakit diabetes cenderung timbul pada usia lanjut. Hal ini disebabkan karena penurunan kondisi fisiologis manusia, yaitu berupa proses penuaan yang diiringi oleh perubahan komposisi tubuh, perubahan neuro-hormonal khususnya penurunan Insulin-like growth factor-1 (IGF-1) dan dehydroepandrosteron (DHEAS) plasma. Penurunan IGF-1 akan mengakibatkan penurunan ambilan glukosa karena menurunnya sensitivitas reseptor dan aksi insulin. Sedangkan penurunan konsentrasi DHEAS ada kaitannya dengan kenaikan lemak tubuh serta turunnya aktivitas fisik. Kondisi ini diperparah oleh perubahan gaya hidup pasien [15].
Penelitian ini juga mendapatkan bahwa hipertensi dan ulkus diabetikum merupakan penyakit penyerta terbanyak pada pasien yang menegalami DM tipe-2. Sedangkan penyakit penyerta lain adalah bronkopneumonia, TB paru, gagal ginjal kronis, anemia, ketoasidosis diabetikum, sepsis, selulitis, urosepsis, dan hiponatremia. Hasil penelitian ini mengkonfirmasi penelitian lain yang dilakukan terlebih dahulu. Mutmainah melaporkan bahwa penyakit penyerta terbanyak pada tahun 2007 di Rumah Sakit X adalah hipertensi dan ulkus diabetikum [16]. Hastuti menambahkan bahwa faktor resiko terhadap ulkus diabetika adalah lama $\mathrm{DM} \geq 10$ tahun, kadar kolesterol $\geq 200 \mathrm{mg} / \mathrm{dl}$, kadar HDL $\leq 45 \mathrm{mg} / \mathrm{dl}$, ketidakpatuhan terhadap diet DM, kurangnya latihan fisik, perawatan kaki tidak teratur dan penggunaan alas kaki tidak tepat

Tabel 1. Gambaran umum pasien yang memenuhi kriteria inklusi $(n=40$ orang)

\begin{tabular}{|c|c|}
\hline Parameter & Nilai \\
\hline \multicolumn{2}{|l|}{ Jenis Kelamin (orang) } \\
\hline Laki-laki & 17 \\
\hline Perempuan & 23 \\
\hline \multicolumn{2}{|l|}{ Umur (tahun) } \\
\hline Rataan (SD) & $49,5 \pm 18,7$ \\
\hline Rentang (min s.d. maks) & 27 s.d. 72 \\
\hline \multicolumn{2}{|l|}{ Komplikasi (jumlah) } \\
\hline o komplikasi & 2 \\
\hline 1 komplikasi & 18 \\
\hline 2 komplikasi & 14 \\
\hline 3 komplikasi & 4 \\
\hline 4 komplikasi & 1 \\
\hline 5 komplikasi & 1 \\
\hline \multicolumn{2}{|l|}{ Riwayat DM (tahun) } \\
\hline$<1$ & 8 \\
\hline $1-5$ & 12 \\
\hline $6-10$ & 9 \\
\hline $11-15$ & 4 \\
\hline$>15$ & 2 \\
\hline Tidak ada keterangan & 5 \\
\hline \multicolumn{2}{|l|}{ Lama Rawat Inap (hari) } \\
\hline$<5$ & 3 \\
\hline $5-9$ & 11 \\
\hline $10-19$ & 15 \\
\hline $20-29$ & 8 \\
\hline$\geq 30$ & 2 \\
\hline Tidak diketahui (pindah ruangan) & 1 \\
\hline
\end{tabular}


[17]. Sedangkan menurut Waspadji, penderita DM dibandingkan dengan penderita non DM mempunyai kecenderungan 2 kali lebih mudah mengalami trombosis serebral, 25 kali terjadi buta, 2 kali terjadi penyakit jantung koroner, $17 \mathrm{kali}$ terjadi gagal ginjal kronik, dan 50 kali menderita ulkus diabetikum [8]. Selain itu DM adalah kontributor terbesar penyebab gagal ginjal kronis [18].

Pada penelitian ini juga didapatkan kebanyakan pasien mempunyai riwayat DM lebih dari satu tahun dan lama rawat lebih dari 10 hari. Pasien yang masuk dalam rentang ini pada umumnya mengalami komplikasi dengan ulkus diabetikum dan TB Paru. Temuan ini dikonfirmasi oleh data nasional yang menunjukkan bahwa rata-rata lama tinggal di rumah sakit pada pasien diabetes dengan komplikasi ulkus diabetikum adalah 59\% lebih lama dari pada mereka yang tanpa ulkus diabetikum [19]. Sedangkan TB paru memerlukan diagnosis yang lebih kompleks dan hasil data laboratorium yang lengkap sebelum menetapkan terapi definifnya. Oleh karena itu, pasien yang komplikasi dengan TB Paru rata-rata akan memiliki masa rawatan yang lebih lama [4].

Pengelolaan pasien DM tipe-2 secara umum dapat berupa terapi non farmakologi dan farmakologi. Terapi non farmakologi meliputi perubahan gaya hidup dengan melakukan pengaturan pola makan (diet), meningkatkan aktivitas jasmani dan edukasi berbagai masalah yang berkaitan dengan penyakit diabetes melitus. Sedangkan terapi farmakologi dilakukan dengan pemberian obat antidiabetik, baik berupa obat antidiabetik oral maupun insulin. Terapi farmakologi pada prinsipnya diberikan jika terapi non farmakologi yang telah dilakukan tidak dapat mengendalikan kadar gula darah hingga mendekati batas kadar normal. Akan tetapi pemberian terapi ini tetap tidak meninggalkan terapi non farmakologis yang telah diterapkan sebelumnya [20].

Pada penelitian ini, obat anti diabetik yang digunakan adalah obat hipoglikemik oral (OHO) dan insulin, baik secara tunggal maupun kombinasi. OHO yang digunakan adalah Metformin, Glikazid, dan Akarbose. Sedangkan insulin yang digunakan pada umumnya adalah Novorapid $^{\circledR}$ dan Levemir ${ }^{\circledR}$. Selain itu juga ada Humulin $\mathrm{R}^{\circledR}$, Humulin $\mathrm{N}^{\circledR}$ dan Novomix ${ }^{\circledR}$ pada sejumlah kecil pasien. Pemilihan obat untuk pasien DM bergantung pada tingkat keparahan penyakit dan kondisi pasien. Penggunaan obat hipoglikemik oral dapat dilakukan secara tunggal atau kombinasi dari dua atau tiga jenis obat. Pemilihan obat yang tepat sangat menentukan keberhasilan terapi. Penentuan regimen obat yang digunakan harus mempertimbangkan tingkat keparahan diabetes (tingkat glikemia) serta kondisi kesehatan pasien secara umum termasuk penyakit-penyakit lain dan komplikasi yang ada [4]. Secara umum, obat ini bekerja meningkatkan sekresi insulin dan hanya efektif pada DM tipe-2 yang tidak kelebihan berat badan. Metformin yang termasuk golongan biguanid bekerja memperbaiki sensitivitasinsulin, menghambat pembentukan glukosa dalam hati, dapat menurunkan kolesterol Low Density Lipoprotein (LDL) dan trigliserida serta berdaya menekan nafsu makan sehingga menjadi obat pilihan utama. Akarbose bekerja menghambat enzim glucosidase dengan demikian pembentukan dan penyerapan glukosa diperlambat, sehingga fluktuasi gula darah menjadi kecil [20,21,22].

Ketika upaya diet dan obat hipoglikemik oral gagal mengendalikan kadar gula darah hingga mendekati normal, insulin dapat digunakan. Penggunaan insulin ini ditujukan untuk mencapai dan mempertahankan kadar gula darah mendekati batas normal untuk mencegah dan menunda komplikasi jangka panjang. Selain itu juga diberikan jika pasien mengalami ketoasidosis, mendapatkan nutrisi parenteral atau memerlukan suplemen tinggi kalori untuk memenuhi kebutuhan energi yang meningkat, mengalami gangguan fungsi ginjal dan hati yang berat atau mengalami kontraindikasi atau alergi terhadap obat antidiabetik oral. Insulin yang digunakan 
dapat berupa insulin dengan masa kerja cepat (rapid-acting) atau yang mempunyai masa kerja panjang (long-acting), baik secara tunggal atau kombinasi. Selain terapi insulin dengan dosis yang memadai, mengurangi semua faktor risiko kardiovaskular sangat perlu pada penangan pasien DM tipe-2 [4,22,23].

Pada analisa kualitatif dilakukan evaluasi terhadap tepat indikasi, tepat penderita, tepat regimen dosis dan tepat rute pemberian. Secara oprasional dalam penelitian ini tepat indikasi adalah bila obat digunakan sesuai dengan indikasinya, sedangkan tepat penderita bila obat yang diberikan tidak kontraindikasi dengan kondisi individual penderita [24].

Pada analisa ketepatan indikasi ditemukan $100 \%$ tepat indikasi, hal ini karena pada penelitian ini kriteria inklusinya adalah pasien DM Tipe 2 yang sedang mengalami rawat inap, tentunya dengan kadar gula darahnya tidak terkontrol dan/ atau mengalami komplikasi. Sedangkan pada analisa ketepatan penderita, ditemukan penggunaan obat antidiabetik yang tidak tepat penderita sebesar $4,41 \%$. Sebagai contoh yang tidak tepat penderita adalah pasien $\mathrm{P} 40$ dengan keluhan klasik DM ditambah mual yang meningkat, perut kembung dan gatal-gatal dibadan. Pasien didiagnosa menderita DM tipe-2 dan kolestatis dengan kadar gula darah puasa $115 \mathrm{mg} / \mathrm{dl}$ dan kadar gula darah postprandial (2 jam) $130 \mathrm{mg} / \mathrm{dl}$, diberikan terapi diet diabetes $1700 \mathrm{kkal}$, Metformin 3x500 mg, Glucodex $^{\circledR}$ 2x50 mg dan Glucobay ${ }^{\circledR} 1$ x50 mg. Pada kasus ini, pasien tidak tepat diberikan ketiga obat tersebut karena dapat memperparah keluhan saluran cerna. Hal ini karena efek samping dari ketiga obat adalah gangguan saluran cerna seperti kembung, mual, muntah dan diare [22]. Pasien memiliki kadar gula darah yang dikategorikan untuk kadar gula darah puasa sedang (110-125 $\mathrm{mg} / \mathrm{dl}$ ) dan kadar gula darah postprandial (2 jam) baik yakni 80-144 mg/dl. Setelah didapatkan hasil pemeriksaan klinik, hal yang dilakukan pertama kali adalah pengaturan diet diabetes 1700 kkal. Jika dengan pengaturan diet diabetes saja belum bisa menurunkan kadar gula darah hingga batas normal, maka diperlukan pemberian obat hipoglikemik oral sebagai terapi awal [25].

Pada analisa regimen dosis, diperoleh $59,18 \%$ pasien yang tidak tepat regimen dosis. Dikatakan tidak tepat regimen dosis bila dosis dan frekuensi pemberian tidak tepat, atau salah satunya tidak tepat. Pemberian obat dengan dosis kurang mengakibatkan ketidakefektifan terapi obat sedangkan dosis berlebih mengakibatkan hipoglikemia dan kemungkinan munculnya toksisitas [4]. Penggunaan OHO dimulai dengan dosis kecil dan ditingkatkan secara bertahap sesuai respon kadar gula darah, dapat diberikan sampai dosis hampir maksimal. Terapi insulin tunggal atau kombinasi disesuaikan dengan kebutuhan pasien dan respon individu terhadap insulin, yang dinilai dari hasil pemeriksaan kadar gula darah harian. Penyesuaian dosis insulin dapat dilakukan dengan menambahkan 2-4 unit setiap 3-4 hari bila sasaran terapi belum tercapai. Bila dengan terapi kombinasi $\mathrm{OHO}$ dan insulin, kadar gula darah masih tidak terkendali, maka obat OHO dihentikan dan diberikan insulin saja [26]. Glucodex ${ }^{\circledR}$ diberikan dengan dosis awal 40 $\mathrm{mg}$ /hari dapat diberikan 1-2 kali sehari. Dosis tunggal $160 \mathrm{mg} /$ hari dan dosis maksimal 320 $\mathrm{mg}$ /hari. Dosis awal Metformin adalah $500 \mathrm{mg} /$ hari 2 kali sehari, dapat ditingkatkan setelah 1 minggu menjadi $500 \mathrm{mg} 3$ kali sehari dengan maksimal penggunaan $2550 \mathrm{mg}$. Untuk pasien belum lanjut usia dapat di berikan $500 \mathrm{mg} 2 \mathrm{kali}$ sehari, sedangkan pasien lanjut usia disesuaikan dengan fungsi ginjal. Glucobay ${ }^{\circledR}$ diberikan $25 \mathrm{mg}$ 3 kali sehari sebelum makan sebagai dosis awal, dapat ditingkatkan menjadi $50 \mathrm{mg} 3$ kali sehari. Setelah 6-8 minggu jika dibutuhkan tingkatkan menjadi $100 \mathrm{mg} 3$ kali sehari, maksimal $200 \mathrm{mg}$ 3 kali sehari [1,23,24,27]. Untuk penggunaan Novorapid $^{\circledR}$ dan Humulin $\mathrm{R}^{\circledR}$ berdasarkan kadar gula darah menggunakan Sliding Scale seperti pada tabel VIII. Untuk indikasi hiperkalemia, diberikan 
dekstrosa 0,5-1 g/kg dengan 1 IU insulin untuk setiap 4-5 g dekstrosa yang diberikan. Humulin $\mathrm{N}^{\circledR}$ pada pasien DM tipe 2 diberikan dengan dosis 0,2-0,6 IU/kgBB/hari dalam 1 atau 2 dosis. Dosis penggunaan Levemir $^{\circledR}$ pada pasien DM tipe 2 diberikan $10 \mathrm{IU} /$ hari atau $0,1-0,2 \mathrm{IU} / \mathrm{kgBB} /$ hari, diberikan 1 kali sehari. Novomix ${ }^{\circledR}$ diberikan 2 kali sehari saat makan pagi dan makan malam dengan dosis 0,4-0,6 IU/kgBB/hari. Ketika digunakan bersama OHO dosisnya 0,2-0,3 IU/ $\mathrm{kgBB} /$ hari [24,27].

Glucodex $^{\circledR}$ digunakan 15-30 menit sebelum makan, Metformin diberikan sebelum/pada saat/ sesudah makan, Glucobay ${ }^{\circledR}$ digunakan sebelum makan atau bersama makan suapan pertama. Untuk Novorapid ${ }^{\circledR}$ diberikan 15 menit sebelum atau segera sesudah makan. Pasien DM tipe 2 dengan terapi insulin, sebelum mendapatkan makan pagi, makan siang, dan makan sore, pasien akan disuntikkan insulin untuk membantu dalam pengendalian metabolisme glukosa dan transpor glukosa dari darah ke dalam sel, sehingga dapat mengendalikan kadar gula darah pasien. Namun, dari data yang didapat, beberapa pasien tidak mendapatkan suntik insulin apabila pasien telah makan sebelumnya. Seharusnya pasien tetap mendapatkan insulin dengan segera sesudah makan, agar insulin tetap dapat mengendalikan glukosa sehingga kadar gula darah tetap mendekati batas normal [23,27].

Pada analisa rute pemberian, tidak ditemukan ketidaktepatan rute pemberian. Insulin pada umumnya diberikan secara subkutan (di bawah kulit), karena absorpsi biasanya terjadi lambat dan konstan sehingga efeknya bertahan lama. Tetapi, pada keadaan tertentu misalnya pada pasien kritis/akut seperti hiperglikemia gawat darurat, atau saat pre-operasi diberikan secara intravena (iv), ini bertujuan agar obat tidak mengalami tahap absorpsi sehingga kadar obat dalam darah diperoleh secara cepat. Selain dalam bentuk obat suntik, saat ini juga tersedia insulin dalam bentuk pompa (insulin pomp) atau jet injector, sebuah alat yang akan menyemprotkan larutan insulin ke dalam kulit [4].

Interaksi obat dikatakan terjadi ketika efek dari satu obat yang berubah dengan adanya obat lain, obat herbal, makanan, minuman atau oleh beberapa

lingkungan kimia. Mekanisme interaksi dapat dibagimenjadi interaksi farmasetik, farmakokinetik dan farmakodinamik. Interaksi farmasetik adalah interaksi fisiko-kimia yang terjadi pada saat obat diformulasikan/disiapkan sebelum obat digunakan oleh penderita [28]. Interaksi farmakokinetik adalah yang dapat mempengaruhi proses obat yang diabsorbsi, didistribusikan, dimetabolisme dan diekskresikan yang bisa disebut interaksi ADME sedangkan interaksi farmakodinamik adalah efek dari satu obat yang diubah oleh kehadiran obat lain di tempat kerjanya. kadang-kadang obat secara langsung bersaing pada reseptor tertentu [29].

Insulin dan antidiabetik oral seringkali berinteraksi dengan obat-obatan lain yang diberikan secara bersamaan. Interasi ini dapat mengakibatkan terjadinya efek potensiasi atau efek inhibisi. Pada penelitian ini ditemukan interaksi farmakokinetik dan interaksi farmakodinamik, sedangkan interaksi farmasetik tidak ditemukan. Interaksi farmakodinamik antara lain terjadi antara insulin dengan ACE-inhibitor (ramipril dan katopril), yang akan meningkatkan efek hipoglikemik insulin, insulin dengan deksametason (kortikosteroid) yang akan menurunkan efek hipoglikemik insulin, insulin dengan betabloker (propanolol) yang akan meningkatkan efek hipoglikemik insulin. Sedangkan interaksi farmakokinetik terjadi antara metformin dengan akarbose (Glucobay ${ }^{\circledR}$ ), dimana akarbose dapat menunda absorpsi metformin sehingga akibatnya terjadi penurunan onset metformin [21,28,29,30].

\section{KESIMPULAN}

Penggunaan obat antidiabetik pada suatu rumah sakit pemerintah di Kota Padang telah tepat indikasi dan tepat rute pemberian. Meskipun 
demikian evelauasi terhadap ketepatan penderita dan regimen dosis belum sepenuhnya sesuai dengan yang diharapkan. Hal lain adalah adanya interaksi obat berupa interaksi farmakodinamik dan farmakokinetik. Oleh karena itu diharapkan kepada rumah sakit untuk menerapkan pelayan farmasi klinik, khususnya asuhan kefarmasian (pharmaceutical care), sehingga pencapaian hasil terapi obat serta keaman pasien menjadi lebih optimal.

\section{DAFTAR PUSTAKA}

1. DiPiro, J.T., Talbert, R. L., Yee, G.C., Matzke, G. R., Wells, B.G., \& Posey, L.M. (2008). Pharmacotherapy: A Pathophysiologic Approach (7th Edition). USA: McGraw-Hill.

2. Wild, S., Roglic, G., Green, A., Sicree, R., \& King, H. (2004). Global Prevalence of Diabetes: Estimates for the year 2000 and projections for 2030. Diabetes Care, 27, 1047-1053.

3. Departemen Kesehatan Republik Indonesia. (2008). Laporan Riset Kesehatan Dasar (RISKESDAS) 2007. Jakarta: Badan Penelitian Dan Pengembangan Kesehatan.

4. Departemen Kesehatan Republik Indonesia. (2005). Pharmaceutical Care Untuk Penyakit Diabetes Mellitus. Jakarta: Direktorat Jenderal Bina Kefarmasian dan Alat Kesehatan.

5. Davey, P. (2005). At a Glance Medicine. Ahli bahasa: Annisa Rahmalia, Cut Novianty. Jakarta: Erlangga

6. American Diabetes Association (ADA). (2007). Diagnosis and Classification of Diabetes Melitus. Diabetes Care, 30, $42-47$.

7. World Health Organization (WHO). (2006). Definition and diagnosis of diabetes mellitus and intermediate hyperglycaemia: report of a WHO/IDF consultation. Geneva: WHO Press.

8. Waspadji, S. (2006). Komplikasi Kronik Diabetes: Mekanisme Terjadinya, Diagnosis dan Strategi pengelolaan. Dalam Aru W, dkk (Editors). IImu Penyakit Dalam, Jilid III, edisi keempat. Jakarta: Penerbit FK UI

9. Arifin, I., Prasetyaningrum, E., \& Andayani, T.M. (2007). Evaluasi Kerasionalan Penggunaan Obat DM tipe-2 Pada Pasien Rawat Inap di Rumah Sakit Bakti Wiratama Semarang Pada Tahun 2006. Jurnal IImu Farmasi dan Farmasi Klinik, 4(1).

10. Setiawan, D., \& Andayani, T.M. (2007). Distribusi Penggunaan Antidiabetik Oral di Rumah Sakit. Pharmacy, 5(1).

11. Primadianti, A., \& Andayani, T.M. (2009). Analisis Efektif Biaya Penggunaan Insulin vs Insulin-Metformin Pada Pasien DM Tipe2. Jurnal Farmasi Indonesia, 4(3).

12. Fitriyani, \& Supadmi, W. (2012). Evaluasi ADR Antidiabetes Berdasarkan Algoritma Naronjo di Bangsal Rawat Inap RS PKU Muhammadiyah Yogyakarta. Jurnal IImiah Kefarmasian. 2(2).
13. Suyono, S. (2006). Diabetes Melitus di Indonesia. Dalam : Aru W, dkk, Editors, IImu Penyakit Dalam, Jilid III, edisi keempat. Jakarta: Penerbit FK UI.

14. Rochmah, W. (2006). Diabetes Melitus pada Usia Lanjut. Dalam Aru W, dkk (Editors), IImu Penyakit Dalam Jilid III edisi keempat. Jakarta: Penerbit FK UI.

15. Mutmainah, N., Ernawati, S., \& Sutrisna, E. (2008). Identifikasi Drug Related Problems Potensial Kategori Ketidaktepatan Pemilihan Obat Pada Pasien Hipertensi Dengan Diabetes Mellitus Di Instalasi Rawat Inap Rumah Sakit X Jepara Tahun 2007. Pharmacon, 9(1), 14-20.

16. Thakar, C.V. (2011). Christianson A, Himmelfarb J, Leonard CA. Acute Kidney Injury Episodes and Chronic Kidney Disease Risk in Diabetes Melitus. Clin. J.Am.Soc.Nephrol., 6, 2567-2572.

17. Yunir, E., \& Soebardi, S. (2006). Terapi Non Farmakologi pada Diabetes Melitus. Dalam Aru W, dkk (Editor). IImu Penyakit Dalam, Jilid III, edisi keempat. Jakarta: Penerbit FK UI

18. Rahardja. K., \& Tjay, T.H. (2007). Obat-obat Penting, Edisi keenam. Jakarta: PT. Elex Media Komputindo.

19. Martin, J. (2011). British National Formulary, 61 edition. London: BMJ Group and the Royal Pharmaceutical Society of Great Britain.

20. Inzucchi, S., Porte, D., Sherwin, R.S., Baron, A. (2005). The Diabetes Mellitus Manual, Sixth Edition. USA: McGraw-Hill

21. Fakultas Kedokteran Universitas Indonesia. (2007). Farmakologi dan Terapi (ed. 5). Jakarta: Gaya Baru: Jakarta.

22. Siregar, C.J.P. (2005). Farmasi Klinik: Teori dan Penerapan. Jakarta: EGC.

23. RSUP. Dr. M. Djamil. (2007). Pedoman Diagnosa dan Terapi, Edisi II. Padang

24. Perkumpulan Endokrinologi Indonesia (PERKENI). (2006). Konsensus Pengelolaan Diabetes Melitus di Indonesia, Jakarta: PB. PERKENI.

25. Anderson, P.O., Knoben, J.E., \& Troutman, W.G. (2002). Handbook Clinical Drug Data 10th ed. USA: McGraw-Hill

26. Schull, P.D. (2008). Nursing Spectrum Drug Handbook. USA: McGraw-Hill

27. Tejani, S., \& Sanoski, C.A. (2009). Davis $\llbracket$ s Pocket Clinical Drug Reference. Philadelphia: F.A. Davis Company.

28. Samanoe, Y. (2012, Oktober 15) Interaksi Obat. http:// pharmacyrspuriindah.blogspot.com/2009/02/interaksi-obat-druginteraction.html.

29. Baxter, K. (2008). Stockley[s Drug Interactions 7th ed. London: Pharmaceutical Press.

30. Elvina, R. (2012). Kajian Aspek Farmakokinetik Klinik Obat Antidiabetik Pada Pasien Diabetes Mellitus Tipe 2 Dengan Gangguan Fungsi Ginjal Di Poliklinik Khusus RSUP. DR. M. Djamil Padang (Tesis Magister Farmasi). Available at http:// Pasca.Unand.Ac.Id/Id/Wp-Content/Uploads/2011/09/KajianAspek-Farmakokinetik-Klinik-Obat-Antidiabetik-Pada-PasienDiabetes-Mellitus-Tipe-2-Dengan-Gangguan-Fungsi-Ginjal-DiPoliklinik-Khusus-Rsup.-Dr.-M.-Djamil-Padang.Pdf. Diakses 17 Oktober 2012. 